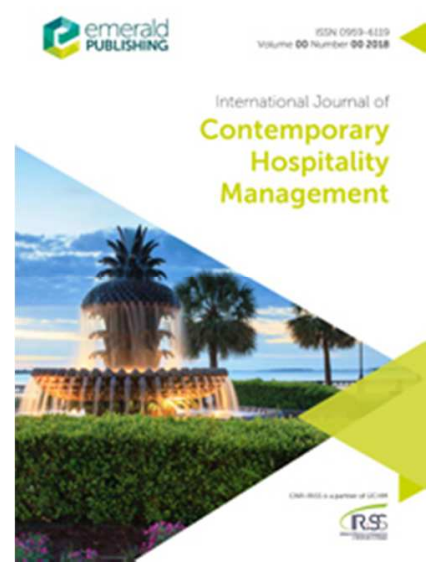

\title{
Discovering lived experiences through descriptive phenomenology
}

\begin{tabular}{|r|l|}
\hline Journal: & International Journal of Contemporary Hospitality Management \\
\hline Manuscript ID & IJCHM-10-2017-0707.R2 \\
\hline Manuscript Type: & Original Article \\
\hline Keywords: & $\begin{array}{l}\text { Phenomenology, Descriptive phenomenology, Lived experience, Music } \\
\text { festival, Husserl, Giorgi }\end{array}$ \\
\hline \multicolumn{2}{|l}{} \\
\hline
\end{tabular}

\section{SCHOLARONE ${ }^{\text {" }}$}

Manuscripts 


\section{Discovering lived experiences through descriptive phenomenology.}

\section{Introduction}

There has been a surge of interest in a phenomenological approach to hospitality and tourism research (Stierand and Dörfler, 2012; Ziakas and Boukas, 2013; Gnoth and Matteucci, 2014; Robinson, et al., 2014; Pernecky, 2016). This is not a new interest. Cohen (1979) and Harper (1981) both called for a more phenomenological approach to tourism and leisure research to aid the discovery of a greater meaning. Harper (1981) espoused the benefits of descriptive phenomenology (hereinafter DP) specifically and that is the focus of this paper. To illustrate a hospitality and tourism experience, the lived experience of the popular music festival-goer is used as the example. Popular and rock music festivals are a global phenomenon. The self-proclaimed largest, ticketed, music festival is Summerfest, Milwaukee, USA with over 830,000 festival-goers over 11 days (Thompson-Gee, 2017). The largest free festival is Donauinselfest in Vienna, Austria, with 2.8 million attendees (Vienna online, 2017). The participants in the example study experienced the Isle of Wight Festival in the UK, a smaller festival of 65,000 . From here on this case study will be referred to as the lived experience festival study'.

Phenomenology provides a way to see the world through a focus on the phenomenon being studied. It can assist in researching those phenomena that are extraordinary or special or those that are mundane and part of the everyday. Phenomenology "is the study of phenomena: their nature and meanings. The focus is on the way things appear to us through experience or in our consciousness where the phenomenological researcher aims to provide a rich textured description of lived experience" (Finlay, 2008, p.1). Phenomenology's ontology is the life-world and viewing phenomena as human beings experience them. It is this focus that appealed when considering how to research the lived experience of the popular music festival-goer. Something so ephemeral and yet corporeal needed to be embraced holistically to capture its complexity. DP is viewed as a human science rather than a natural science and so has a particular Dasein view of the relationship between subjects and objects and how things are realised and perceived (Giorgi, 2009). The aim of this paper is to explore why and how DP can offer an enriched understanding of experience. This will be achieved through meeting two objectives in this paper.

Firstly, there are many ways of seeing the world and this paper discusses and illustrates how a descriptive phenomenological methodology is one way of getting to the heart of a phenomenon through the consciousness of participants. Phenomenological research is about "going back to people's specific experiences and letting the concepts come from there" (Todres and Holloway, 2010, p183). DP is an existing philosophical approach to research, which has rarely been applied to hospitality, tourism and event studies. Since the work of Pernecky and Jamal (2010), there has been some interest in discovering experiences through phenomenology but few have been able to explore the philosophy or the practice involved within the constraints of a journal article. This special issue offers this opportunity. In the literature review section of this paper there are a number of philosophical concepts of phenomenology that are outlined and discussed. These concepts are fundamental to understanding and accepting the philosophical and 
ontological view of DP before any epistemological application is undertaken. The first objective of this paper is to reveal the complexities and philosophical depths that DP affords the hospitality, tourism and event researcher.

The traditional findings section of this paper will focus upon the DP methods used in the lived experience festival study. Psychologist, Giorgi (1994, 2009) developed the descriptive phenomenological method and this was used as the basis for this study. Giorgi's method is based upon the early twentieth century philosopher Husserl's scientific approach to developing phenomenology. Giorgi's approach (2009) offers a robust process for analysing situated experiences that gives a clear insight into a phenomenon. This paper will discuss the reasons and challenges involved in adopting DP within the context of the Isle of Wight Festival. The second objective of this paper is to outline a method that puts the philosophy of descriptive phenomenological into research practice. The methodological steps adopted and developed from Giorgi (2009) to undertake the lived experience festival study are used illustrate this.

\section{Descriptive Phenomenology - the philosophy}

Despite various adaptations of phenomenology (van Manen, 1990; Smith, 2010), there are two distinct branches to be considered, the descriptive and the hermeneutic or interpretive. The first branch, descriptive phenomenology, which was adopted for the lived experience festival study, was developed from the philosophies of the earlier works of Husserl (b1859-d1938), a philosopher and a mathematician. Husserl (Husserl, 1965 [1911]) was concerned about ensuring the rigorous nature of a scientific approach and this is evident in his (and latterly, Giorgi's) descriptive nature of participants' experiences. The second branch, the hermeneutic phenomenological approach, was developed by those who took their lead from Heidegger (b1889-d1976), a disciple of Husserl. Hermeneutic phenomenology is less objective and more personal (reflexive) on the part of the philosopher (researcher). It is referred to as interpretive phenomenology because it takes an interpretive rather than a descriptive method of analysis (Finlay, 2008, 2009; Reiners, 2012; Matua and Van Der Wal, 2015).

The significance of these differences becomes clearer when developing and applying the DP method to the lived experience festival study. The following concepts explain the significance of some of the main philosophies that were found to be fundamental to an understanding of the ontological approach that DP afforded the researcher. They underpin the rationale for choosing DP for the research of a hospitality, tourism or event experience. Those chosen illustrate why DP is effective in revealing the "hidden aspects" of experiences (Matua and Van Der Wal, 2015, p.23).

\section{Life-world (Lebenswelt)}

The lived experience approach of phenomenology offered a well-grounded philosophy for the lived experience festival study. "The overall aim of lifeworld research is to describe and elucidate the lived world in a way that expands our understanding of human beings and human experience" (Dahlberg et al., 2008, p.37). Both descriptive and interpretive approaches to phenomenology attempt to investigate the lived experience' (Erlebnis) of the 'life-world' (Lebenswelt). Husserl's main concern was an epistemological one; to provide a foundation for knowledge through the study of 
Lebenswelt (Husserl, 1965 [1911], 1999 [1936]). DP looks to a phenomenon as experienced by the participant from a Dasein holistic, not Cartesian dualist perspective (Langdridge, 2008; Pernecky and Jamal, 2010). The relevance to the lived experience is that there is no dualist view of the subject and the object or the mind and body. Within the life-world the phenomenon is inextricably linked with the subject and so underpins the view that access to a phenomenon is through the participant (Finlay, 2008). One critic of phenomenology, Paley (1997, 2014, 2017), has not acknowledged this philosophical stance and so struggles to understand or accept it. The primary goal of DP is to better understand a phenomenon as experienced by a participant in their lifeworld. Interpretive Phenomenology is also concerned with 'being-in-the-world', of the context that the life-world affords the participant (Stierand and Dörfler, 2012; Matua and Van Der Wal, 2015).

\section{Morphological essence}

The aim of the example study was to provide an understanding of the lived experience of the popular music festival-goer. It was necessary to therefore seek to identify and understand better the particular phenomenon, the essence of experiencing a music festival. The descriptive phenomenological philosophy originated by Husserl (1982 [1925]) and more recently developed by Giorgi (2009), offered the most faithful way of doing this. It was the most attractive approach because it did not claim that a definitive position of an exact essence could be achieved. Giorgi (2009) has argued that although the phenomenologist would seek the most universal essence, what is really sought is "the structure of the concrete experiences being analysed through the determination of higher-level eidetic invariant meanings that belong to the structure" (Giorgi, 2009, p.100). These are regarded as 'morphological' essences because they are inexact and could be different when researched at another time (Giorgi, 2009). These morphological structures are however regarded as general findings; which is not always the case in qualitative research. The descriptive nature of DP aims "to find insights that apply more generally beyond the cases that were studied in order to emphasise what we may have in common as human beings" (Todres and Holloway, 2010, p.178). This underpins the methodology and the method and why it is the richness of the descriptions of experiences that are paramount not the number of them.

\section{Irreal}

One of the identified strengths of DP from the lived experience festival study was that it gave agency to the experience as described by the participants in the study. Husserl's view of phenomenology allowed for 'irreal' objects, as well as for real. DP accepts that there are both real and irreal features of an experience and that it is the irreal that affords greater depth of understanding and identification of the phenomenon itself. Real objects are located in space, time and causality. An irreal object lacks one or all of these attributes, like a sense of justice or an atmosphere. The real and irreal are both objects of consciousness to the phenomenologist (Husserl, 2001 [1901/1913). Real objects can exist independently of consciousness, but irreal, experiential phenomena, cannot (Husserl, 1982 [1925]). This is why the consciousness of the participants is used to identify an ephemeral experience such as a popular music festival, which is made up of real and irreal objects. This method is more holistic and gets to the richness of the experience because "the 'life-world' is always more complex than anything we can say about it: the lived is greater than the known" (Todres and Wheeler, 2001, p.3). 


\section{Intentionality and Noema}

It is through the pre-reflective recounting of having been to a popular music festival that formed the basis of the lived experience festival study. The aim was to gather the festival experiences of the participants by intentionally relating to their consciousness. This is achieved by going to the consciousness of participants, which itself is stretching out towards into their life-world. Husserl (2001 [1901/13]) labelled these units of consciousness 'intentional acts' or 'intentional experiences'. Intentionality includes the sense of 'what it is like' and relies upon a holistic capturing of consciousness when doing research. In phenomenological literature, meaning is often discussed in terms of the noematic and 'what' of experience (Føllesdal, 1990; Langdridge, 2008; Christensen et al., 2017). The noematic concerns the meaning or meanings of an experience. It is how and when the meaning of the experience manifests itself that is important. Schutz (1972 [1932]) believed that it is through explicit retrospection that greater meaning manifests itself. The meaning is recovered and re-enacted; for example, in remembrance, narration, meditation; or more systematically, through phenomenological interpretation. When researching the lived experience of the popular music festival-goer in the philosophical attitude of DP it became clear to the researcher what was meant by the particular features described in this paper. The power of the conscious nature of the phenomenon under study was more significant than individual described experiences. The strength of understanding manifested itself through the consciousness of the researcher through the stages of analysis, through the DP method discussed in the next section.

\section{Descriptive Phenomenology - the method}

The methodology chosen for the lived experience festival study was based on the phenomenological philosophy of Husserl (1965 [1911]) and the scientific descriptive phenomenological method in psychology of Giorgi (2008, 2009, 2010, 2012, 2017; Giorgi et al., 2017). Giorgi's methods were developed nearly a century after Husserl's original writings with the aim of developing a rigorous descriptive empirical phenomenology by focusing upon essential structures or essences of phenomena as they appear in consciousness (Giorgi and Gallegos, 2005; Giorgi, 2009). Bringing together a method that was both scientific but also qualitative was appealing to the researcher of the lived experience festival study. These approaches afforded an opportunity to be independent and rigorous at the same time as being open to what the lived descriptions presented as the phenomenon. Phenomenological research is based on a mode of discovery used to clarify what the consciousness receives, not a mode of verification to confirm a theory-laden hypothesis about what is given.

The lived experience festival study adopted and adapted the series of practical steps that Giorgi had developed and applied to psychological contexts. Giorgi (2009) describes the whole research process from identifying a researchable problem through to the interpretation and communication of the findings. He however identifies the method as one of the essential factors in this process. Having undertaken the whole research process to discover the experience of the music festival-goer, it is considered necessary to treat the last factors, of interpretation and communication, as actually being additional steps within the method. Even for Giorgi, the number of steps in his 
method has changed during different applications and explanations (Giorgi, 2008, 2009, 2012, 2017). Giorgi (2012) eventually settled on five 'concrete' steps. This indicates the organic nature of the method and research in general, and also the rigour involved in auditing and understanding the application of the principles of the method. The seven steps proposed by this paper, as an adapted version of Giorgi's method, are summarised in Table I. The numbers in the brackets of the concrete steps are those identified from when Giorgi (2012) updated them from his book, which describes his method in detail (Giorgi, 2009). These steps and their most significant characteristics are discussed in the following sections in relation to the lived experience festival study.

\section{***INSERT-TABLE-I-HERE***}

\section{Step 1. Concrete descriptions}

The first step identified, to collect concrete descriptions, is added here to Giorgi's (2012) steps because a researcher adopting DP for the first time needs to ensure that the collection of raw data follows a DP method. The founding of good phenomenological research is the acquisition of concrete descriptions of the phenomenon under study. An understanding of the philosophy has distinct applications in the method.

\section{The participants}

For the lived experience festival study, ten participants were interviewed within a week of them having returned from a multi-day, green-field, music festival. Giorgi (2009) argues that, in his method of phenomenology, the research uses depth strategies and not sampling strategies that rely on the number of people interviewed. What is important is that participants have experienced the phenomenon being studied, rather than adopting a variation sampling method where, for example, the researcher seeks out those with a wide variety of demographic characteristics (Langdridge, 2008; Holloway et al., 2010). In arguing for more than the one 'self' experience evident in philosophy, Giorgi (2009) stated that at least three participants are needed for his method of DP and found more than this difficult to write about (Giorgi and Gallegos, 2005). In other descriptive phenomenological studies, the number has ranged between three and fifteen (Giorgi B., 2011; Broomé, 2013). It has been found that "the most profound insights with in-depth reflections [are discovered with] ... about six to 12 cases as 'windows' to, and illustrations of, a phenomenon. There is danger in choosing a sample that is too large" (Todres and Holloway, 2010, p.183).

\section{The phenomenological interview}

The principal method used by phenomenologists to gain descriptions of experiences, is the one-to-one interview (van Manen, 1990; Finlay, 2008; Giorgi, 2009). All the participants interviewed in the lived experience festival study were asked to: "describe to me your experience of the last music festival that you went to." Participants were asked to further describe particular moments that they mentioned as they told their story. Probing questions, such as: 'can you tell me more about when you said...?' and 'can you give me an example of when you said you felt...?' It was important is to ask participants to describe their experience, not to explain it. In practice, this was a challenge. The interviewer does not direct the interview, as in a structured or semi-structured interview, with set topics to cover, but does probe further, using the words of the interviewee to do so. This is to ensure that "as complete a description as possible of the 
experience that a participant has lived through" is captured (Giorgi, 2009, p.122). DP research focuses on the consciousness through the descriptive interview because, "communication of our lived experience is all we can have access to when attempting to understand the way the world appears to people" (Langdridge, 2008, p.1128). DP is not concerned with the way the world appears to the researcher, which is why the next step relates to one of Husserl's unique and most criticised techniques, that of the epoché or bracketing.

\section{Step 2. Sense of the whole (and bracketing)}

In the lived experience festival study, once the transcription of the interviews was complete, reading and re-reading the transcripts was necessary in order to get a sense of the whole. This was done within the attitude of phenomenological reduction (Giorgi B, 2011; Giorgi, 2012). This meant that, in practice, the researcher prepared herself by undertaking three positioning tasks. Firstly, the researcher ensured that she was physically and mentally immersed in the research process when reading the transcripts. This aided and opened her mind to what the data was saying. Secondly, the researcher bracketed out prior knowledge of the popular music festival experience so that whatever was given in the data is what was said about it. This included the other interviews and personal experiences. Thirdly, the adopted attitude (Giorgi, 2009) included special sensitivity to the specific phenomenon investigated. In practice this was listening to what the participant said and, even though it was the words on the paper that were being transformed, the voices of the participants were still evident in the researcher's mind.

In this whole process, the descriptive phenomenologist 'brackets', or 'suspends', prior knowledge and beliefs about a particular phenomenon. It is this aspect of phenomenology that interpretive phenomenologists disagree upon, although Langdridge (2008) believes that this difference is overplayed. It is claimed that by bracketing past knowledge, a researcher has the possibility of developing a new approach to the raw data. This enables "the noetic-noematic relation to come to the fore... That is, the particular way in which the describer's personal acts of consciousness was enacted to allow the phenomenal intentional objects to appear" (Giorgi, 2009, p.100). To ensure that the researcher can reach out to the phenomenon that is consciously recognisable through the process of intentionality, it is argued that the adoption of the phenomenological attitude should be taken and that what the participant describes should be accepted without value judgement. In practice "...'bracketing' can bring a certain discipline and rigour that realises fresh insights beyond the preconceptions of the researchers" (Todres and Holloway, 2010, p.181). Bracketing is a challenge in practice because the researcher cannot totally blank out what they know and what they feel (Finlay, 2009). The claim is not that they will achieve this but that being conscious of who they are and the DP method, means that the researcher is able to ensure that they give primacy to the words of the participant and the phenomenon under study.

\section{Step 3. Meaning units}

Steps three and four are where Giorgi has clearly developed methods that are unique to his version of descriptive phenomenology. The process involves determining the meaning units of each description of an experience on the transcript. The transcript is 
broken into parts, after reading from the beginning again, to keep that 'sense of the whole' that was identified as important in the previous step of the method. This process proceeds spontaneously and experientially, rather than intellectually (Giorgi, 2009). In practice, this step was not a matter of breaking the transcript into 'natural' sentences or paragraphs but the researcher intuiting a shift in meaning. In practice, this is really challenging, despite what appears to be a simplistic process. Every significant shift in meaning is identified with a red slash, which is not necessarily positioned at the end of a sentence. A small sample of the transcript from participant $2\left(\mathrm{P}_{2}\right)$ is included in Figure 1 to illustrate this process. This example will be used through the next steps to demonstrate the process.

\section{***INSERT-FIGURE-1-HERE***}

The first break in meaning in this example is the disappointment of $\left(\mathrm{P}_{2}\right)$ at not being able to enjoy the sun and drinking alcohol with her friends. The next meaning unit is when the mood changes to a more positive one when $\mathrm{P}_{2}$ describes how her friends were able to enjoy themselves and she could actually join in because somebody played the ukulele and she was able to join in singing. The third meaning unit was the going into the festival and the disappointment at how the sheer scale of the festival meant that $\mathrm{P}_{2}$ was unable to watch the band she wanted to see up close and intimate.

In the lived experience festival study, the process of meaning unit identification was achieved by constantly reading the transcript from beginning to end with sensitivity to the specific phenomenon being investigated, the music festival experience. In practice, given the volume of ten transcripts to work with, overlooking some material was a possibility and so having manageable sized meaning units ensured that all relevant content of the transcripts was included. The 381 pages of transcript resulted in 921 meaning units. These were then copied and pasted into a table for Step 4 (Table II). In the later stages of analysis it was difficult to keep the whole transcript in mind and so this step in the process helped to ensure that the whole was considered because the meaning units were identified in the tables that were created for the next, transformation step.

\section{Step 4. Transformation - reduction and intuition}

The systematic approach used within step 4 was made up of a number sub-steps and was the most challenging, but also the most informative stage of the process for the researcher. Giorgi described the step of transforming the meaning units as "the heart of the method" (2012, p.6). The interrogation of each meaning unit was to express, in a more satisfactory way, the implications of the life-world descriptions given by the participants (Giorgi, 2009). The identification of the 'meaning' occurs at this point. This requires transforming the meaning units, which are in everyday language, through reduction and formality, to words that better reveal the characteristics of the experience. It is a process of 'explicating' a meaning unit as "an intuitive accomplishment (in the Husserlian sense of intuition), and is verified through the researcher's perception of a meaningful whole" (Applebaum, 2012, p.49). To aid the process of transformation, a table of meaning units, and their transformation, was created (Table II). The researcher decides the number of times a meaning unit goes through the process, and therefore the number of columns required in the table. It is reliant on the researcher to detect, draw out and elaborate what this is, through 'free 
imaginative variation' (Giorgi, 2009). This depends upon how confident the researcher is that the final column is the ultimate transformation, which will be used in step 5, "to ensure the eidetic status of the meaning to be described" (Giorgi, 2009, p.154).

\section{***INSERT-TABLE-II-HERE***}

Table II demonstrates how the three meaning units identified in Figure 1 were transformed by using Giorgi's method of imaginative variation. After all of the 921 meaning units created from the ten transcripts were transformed, the identification of the constituents through colour coding was undertaken in the final column.

In practice, this stage needed time and space to focus on the task in hand. The number of sub-tasks involved related to each of the columns illustrated in Table 2. This involved: creating the units of meaning (column 1) that were identified in step 3 (Figure 1); rewriting them in the third person (column 2); transforming them into everyday language (column 3) and then employing the use of imaginative variation (column 4). This step resulted in the researcher being closer to what was said, rather than assuming what was said. This is an example of where the DP method is clearly more independent than other methods. It was a challenging task to get beyond hearing the participant voices when trying to change the language being used in the identified meaning units. It was hard not to add in explanations or embellishments about participant experiences. As part of this process it is imperative that, "one neither adds to nor subtracts from the invariant intentional object arrived at, but describes it precisely as it presents itself" (Giorgi, 2009, p.137). The displaying of the process in a table and columns was not only transparent but also useful for the process of transformation. By viewing the transformed meaning units juxtaposed, the 'sense of the whole' was more apparent. Otherwise, it became tempting to identify each individual meaning and not to see the relationships between them. This was important for the next step in the process, the identification of the constituents and the overall structure of the experience.

\section{Step 5. The Structure}

The fifth step (Giorgi's fourth step) identifies and illustrates the overall findings from the analysis. Through the experience of the process, this step is split into three substeps to better explain the process that is gone through to discover the final essential structure. It was discovered that there were distinct differences between identifying the constituent parts, forming the structure and the narrative of the constituents. Each constituent relies upon the other, because the overall structure would fall apart with the removal of one of the essential constituents. Constituents cannot be independent of each other and so therefore take into account the holistic view, as identified in step 2 . This procedure grounds itself in the philosophical concept of parts and wholes, which expresses the idea that the whole of some things are irreducible to its parts. In other words, the value of the whole is greater than the sum of its parts. This however does not mean that the research ignores outliers, as in quantitative data. In phenomenology, these are classified as variations. Variations of constituents are where particular constituents are identified, but are not evident, within all participant experiences (Giorgi, 2009). There are also possibly variations within constituents, where there are differences in how a particular constituent is experienced. These would be identified as each constituent is discussed and illustrated in the findings of a piece of research. 


\section{Constituents}

The final columns of the transformed participant transcripts highlight each of the topics intuited (Table II). Not all meaning units highlighted proved to be useful because some were superfluous or not relevant to the phenomenon itself. Identifying the constituents seemed to the researcher to be similar to, but different from, the themes or codes of other qualitative research methods. The process was undertaken by categorising a number of smaller, separate subjects, as a collective theme does. Constituents are, however, heavily context driven, interdependent, and should be understood in their relationship state. Essentially, the constituents of the experience are synthesized using imaginative variation to examine the transformed meaning units to discern those that could be categorized as 'the same', or 'shared', in their essential meaningfulness, across the different participants' accounts. What was produced was a number of second-order descriptions that, in Husserl's theory of meaning (2001 [1900/1913]; Giorgi, 2009), were the specific objects of the consciousness of the experience of the popular music festival-goer. In the lived experience festival study, colour coding was used as demonstrated in Table II and followed through into Figure 2.

\section{Essential structure}

The process of recognising and better understanding the constituents was an integral part of the second stage of step 5, the eidetically identified essential structure of the phenomenon (Giorgi, 2009). The general 'structure' of the phenomenon is found from the 'essential', or invariant, constituent parts of all of the experiences (Harper, 1981; Giorgi, 2009). There was an inextricable link with the identification of the constituents, but the identification was undertaken post constituent identification as a separate task. It was the making of the implicit explicit because "the phenomenologist looks for those necessary features which make a thing what it is" (Harper, 1981, p.117). The process required a stepping away from the tables to achieve a generalisation because the researcher was required to integrate data from the participants into one structure (Figure 2). Giorgi claims that this does not push findings to a level of universality (the claim of philosophy), but to a generality that is appropriate for revealing the characteristics of a phenomenon (Giorgi, 2009). This is at an eidetic level but still rooted in the context. This is a nomothetic not an idiographic result. It enables the phenomenon, and not the participant, to be the focus of analysis (Giorgi, 2008, 2009). This step required that any intra- and inter- structural differences and similarities between the constituents were identified.

***INSERT-FIGURE-2-HERE***

\section{Step 6 Communication}

The final two steps (Table I) are additions to those identified by Giorgi as part of his method of descriptive phenomenology. They were included as separate steps because, in practice, the activities undertaken in these stages continued the process of analysis evident in steps 4 and 5 particularly. When the constituents and their inter- and intrarelationships were identified they can be communicated in three main ways.

The first step is through visualisation, by creating a figure or model that depicts the nature of each constituent and any particular relationships that they have with each 
other. Constituents do not necessarily have to be integrated but in this study of the popular music festival they were found to be. The constituents identified were the, apparently, bipolar semantic opposites of freedom and constraint, camaraderie and hostility and euphoria and despair. The key constituents of the structure of the popular music festival experience were drawn as six named intersecting circles with a central seventh circle, being the elements that link that positives and negatives together (Figure 2). For Freedom and Constraint it was the mundanity of the experience that was the neutral nature of the experience. For Camaraderie and Hostility it was the moments when the experience was one of solitude. For the extremes of euphoria and despair, there were also moments of indifference. In previous studies on music festivals, and even of other hospitality and tourism experiences, there has been limited identification of the potentially negative nature of the experience. Without the DP method, these may have been overlooked as part of the phenomenon.

The second step is one of writing in detail about each of the constituents and their interand intra- relationships. This is the constituent narrative that forms an important part of the findings and uses the original voices of the participants themselves. In other types of study these findings are often directly related to existing literature and relayed in academic terms. This is not the case with descriptive phenomenology. It was during this sub-step that the researcher discovered potential duplication given the challenges of terminology and language. The final iteration of the structure of the popular music festival experience contained seven constituents (Figure 2) and not nine that had originally been identified. It became apparent at the final stage of Giorgi's method, of analysing the raw data, that there were too many similarities between freedom and excitement with anger, stress and frustration that they were re-categorised. The writing up and communicating the constituents through direct quotes from the original transcripts, rather than the transformed meaning units, gave primacy to the words of the participants. These were not as examples of the participants themselves, as in some other forms of phenomenology (van Manen, 1990), but as descriptions of the constituents. The challenge of this step was describing the individual constituents and their relationship to each other without reference to any literature or any valuejudgements on behalf of the researcher.

\section{Step 7 Interpretations}

The structure and its constituents are then discussed in relation to relevant academic literature. This step also requires an element of meta-analysis, of seeing the relevance and significance of the findings and identifying relevant literature that further expand the understanding of the phenomenon. For the lived experience festival study this resulted in a number of discussions around: State of Being; Being with Others and States of Emotion. The literature used in these discussions was gathered from different academic fields, from leisure, psychology, geography and cultural studies. The wider literature assisted with an even greater understanding of the nature of the lived experience of the popular music festival-goer. It also identified the limitations of existing knowledge of experience. For example, taking the camaraderie and hostility constituents, there is literature that relates to intimate interaction and intimate relationships but very little on dysfunctional intimacy.

These steps, if followed, inform the process of undertaking DP research. DP does take more time than other methods to deploy because of the number of stages involved. It 
does however ensure a rigorous and transparent process. In practice, it also ensures that the researcher focuses wholly on the experience being researched. It gives a deeper but also wider perspective of the phenomenon being studied and encourages engagement with multi-disciplinary bodies of literature.

\section{Conclusions}

\section{Theoretical implications}

The DP methodological approach is what Giorgi (2009) describes as pre-theoretical. It is about building understanding and is therefore knowledge based. Whilst the method is descriptive, the process is analytical and enlightening. The lived experience festival study has demonstrated that this particular phenomenological approach can explore the complex nature of the festival experience. It also illustrates how it has the potential to further investigate the different constituents of the phenomenon. It achieves this by recognising the primacy of the participant experience, rather than the preconceived ideas of the researcher. Existing academic literature has been predominantly focused on the positive aspects of leisure, tourism and events, including its relevance to Positive Psychology (Stebbins, 2018). The advantage of using the descriptive phenomenological method has been that the telling of the whole story, as remembered at the time of the interviews, included a lot of detail and not just the most vivid moments of euphoria and intense intimacy but also times of stress and despair. It would have been too easy to exaggerate these and to elevate the positive over the negative. This is especially true when recognising that most other research and discussions in the literature have focused on the positive. It was also a general focus of the interviews, where apart from one, and to a lesser extent, a second participant, all wanted to reinforce the positive nature of the experience and that they were looking forward to their next festival. However, all participant descriptions included negative experiences and times of mundanity, the in-between times.

\section{Practical implications}

The use of DP not only provides the academic with a deeper understanding but also that of the practitioner. In the lived experience festival study, for example, a deeper understanding of the phenomenon would assist practitioners in all of the stages of managing the festival experience (pre-, peri- and post). It would particularly aid their appreciation of the actual festival experience rather than the planning, programming and operations and whether interventions (activities and services) or environments facilitate the maximisation of the experience for festival-goers (whether peak moments or spaces for solitude). As the marketplace for popular music festivals has become more saturated and competitive, it is important to understand not only the festival-goers' motivations but also their actual experience. This would enable better-designed festivals that increase satisfaction by providing for and encouraging hedonistic behaviour and socialisation for optimal emotional arousal. Whilst the music at popular music festivals stimulates hedonistic and emotional behaviours, the other festival-goers and in particular, those existing friendship groupings that pre-date the festival, are important factors for the managers and marketers of festivals to take into consideration whilst planning pre-event activities and communication.

\section{Limitations and future research}


There is no universal acceptance of phenomenology. Paley $(1997,2014,2017)$, for example, is a vociferous opponent of phenomenology and attacks its claims of meaning and morphological essence. When trying to follow Paley's arguments $(1997,2017)$ it becomes evident that he identifies with a Cartesian view of the world. Paley sees the lived-world as made up of objects that can be best captured by observation rather than from the participants themselves. This is based on his premise that there are two types of 'things' an individual might report on: 'observable events' and the 'subjective stream'. However, the Dasein view of phenomenology is that they are one, both object and subject. Paley confuses the Cartesian and a Dasein view of 'being-in-the-world' and so refutes the Dasein view that they are one. This may be because Paley takes literally the lived experience and has not explored further the nature of consciousness and the understanding of the noematic that is the basis of many discussions and interpretations in the phenomenological literature (Føllesdal, 1990; Zahavi, 2008). The main limitations of DP are the necessity to thoroughly understand the philosophical nature of the approach and many of the details related to a recognition of being in the world (Smith, 2016; Christensen et al., 2017). This paper goes some way to explain and illustrate one of these methods, that of descriptive phenomenology.

There are significant variations between the different methods of phenomenology that need to be considered when deciding which to undertake. There is a need for future research that directly compares the different approaches to phenomenological research and the potential outcomes that are achieved. There has also been some interest in mixed methods research that brings the different methods together in a single study (Mayoh and Onwuegbuzie, 2015). The opportunities for adopting a phenomenological approach in hospitality, tourism and event research offers the benefits already accepted in other fields such as nursing, social services and education. This postmodern perspective of human experience offers the researcher a richer, more life-world, appearance of the phenomenon under study. This requires other researchers to adopt this methodology for their research of hospitality, tourism and event experiences. Only with application can we experience the benefits of DP. Only with practice can we perfect its limitations.

\section{Conclusion}

There are three main reasons for choosing Husserl's descriptive phenomenological approach and Giorgi's method for the study of any hospitality, tourism or event experience. Firstly, the originality of a descriptive phenomenological approach offers a new insight into a phenomenon. Phenomenology is used in a number of professional practices other than hospitality, tourism and events, such as psychology (Giorgi, 2009), nursing (Todres and Wheeler, 2001; Todres and Holloway, 2010) and education (van Manen, 1990). It affords the researcher holistic and authentic insights that are based upon the consciousness of the participant. This paper has outlined, explained and illustrated a philosophy and methodology that can be used in hospitality, tourism and event research. The method of applying Husserl's philosophy to the lived experience festival study and the identification of new steps and sub-steps, offer the researcher a systematic and methodical process to follow.

Secondly, DP and the methods described in this paper are most appropriate if the researcher is not personally involved in the experience itself, either as participant or observer. Whilst the followers of Heidegger argue that the strength of the hermeneutic 
approach is the personal involvement of the researcher in the interpretation of the phenomenon under study, Giorgi (2009) argues that the prescription of his process does not negate the personal but the individual inconsistencies. This is the phenomenological attitude taken during the analysis stages of the method and is directly related to the employment of bracketing. The aim in the lived experience festival study was not to hear the stories that participants wanted people to hear but to get to the heart, the essence, of what it was like to experience a popular music festival, without influence from preconceived ideas on the part of the researcher and the participant. It is only at the discussion stage of findings that other views of the world are referred to. This is so that the researcher remains sensitive to the participant and their experience and then to the phenomenon itself when moving beyond the individual experiences.

The third reason for choosing DP is its claim of scientific rigour (Harper, 1981; Giorgi, 2009, 2017; Smith, 2016). The stepped process (Table I) is attractive as a means of undertaking a transparent and structured process of data collection and analysis. Whilst there have been criticisms that Giorgi is too prescriptive in his methods (Smith, 2010). Giorgi argues that "the ability to check the results of a study or to replicate it is a scientific criterion, and phenomenologically grounded science accepts that criterion" (Giorgi, 2010, p.7). It is the process, not the findings, that are replicable and that repeating the research could result in different discoveries. This is true of quantitative research as well, where the type of analysis is where the rigour and replication is and that new data may have different results. DP is not only philosophically rooted but also has a systematic method that answers some of the critics of the elusive nature of theming evident in other qualitative research methods. DP is a bridge between two different paradigms and offers both the robustness of science and the sensitivity of qualitative paradigms.

Overall, the philosophical and methodological groundings of DP discussed in this paper can offer a deep understanding of experience, and further insights for hospitality, tourism and event research. Experience is a major research interest and there have been many calls to better understand this within the context of hospitality, tourism and events (Jackson et al., 2009; Tung and Ritchie, 2011; Walls, et al., 2011; Rivera and Pizam, 2013). This paper offers an alternative and effective way of better understanding the nature of the experience and its meaning. What DP affords the researcher is an understanding of the life-world and a realisation that experience is concurrent with the world within which people live and which they consciously express to themselves and others, pre-reflectively. Using DP was like going 'back to basics' to find out what it was to have experienced a popular music festival. The research had no 'agenda' and focused on what the experience was, as remembered by the participants. It is the whole experience, the real and irreal, which was studied. Rather than the participant or the researcher explaining the experience by judging and making assumptions, it was the descriptions of experiences that were used to get to the morphological essence of the experience of the festival-goer. What resulted was an eidetic structure whose constituents were detailed and invariant in nature. This approach captured the complexity inherent in the consciousness of the experience and illustrated it in an essential structure. Giorgi explained that the structure is not a definition of the phenomenon but a depiction of "how certain phenomena that get named are lived, which includes experiential and conscious moments," (Giorgi, 2009, p.166). 


\section{References}

Applebaum, M. (2012), "Phenomenological Psychological Research as Science”, Journal of Phenomenological Psychology, Vol. 43, pp. 36-72.

Broomé, R.E. (2013), “The Lived-Experience of Leading a Successful Police Vehicle Pursuit: A Descriptive Phenomenological Psychological Inquiry", Journal of Phenomenological Psychology, Vol. 44, pp. 220-243.

Christensen, M., Welch, A. and Barr, J. (2017), "Husserlian Descriptive Phenomenology: a review of intentionality, reduction and the natural attitude", Journal of Nursing Education and Practice, Vol. 7 No. 8, pp. 113-118.

Cohen, E. (1979), “A Phenomenology of Tourism Experiences”, Sociology, Vol. 13, pp. 179-201.

Dahlberg, K., Dahlberg, H. and Nystrom, M. (2008), Reflective lifeworld research, $2^{\text {nd }}$ edition, Studentlitteratur, Lund, Sweden.

Finlay, L. (2008), "Introducing phenomenological research", available at: www.lindafinlay.co.uk (accessed 1 November 2008).

Finlay, L. (2009), "Debating Phenomenological Research Methods”, Phenomenology \& Practice, Vol. 3 No. 1, pp. 6-25.

Føllesdal, D. (1990), "Noema and Meaning in Husserl”, Phenomenology and Philosophical Research, Vol. 50, pp. 263-271.

Giorgi, A. (1994), "A Phenomenological Perspective on Certain Qualitative Research Methods", Journal of Phenomenological Psychology, Vol. 25, pp. 190-220.

Giorgi, A. (2008), "Concerning a Serious Misunderstanding of the Essence of the Phenomenological Method in Psychology", Journal of Phenomenological Psychology, Vol. 39, pp. 33-58.

Giorgi, A. (2009), The Descriptive Phenomenological Method in Psychology. A Modified Husserlian Approach. Duquesne University Press, Pittsburgh.

Giorgi, A. (2010), "Phenomenology and the Practice of Science", Existential Analysis, Vol. 21 No. 1, pp. 3-22.

Giorgi, A. (2012), “The Descriptive Phenomenological Psychological Method”, Journal of Phenomenological Psychology, Vol. 43, pp. 3-12.

Giorgi, A. (2017), "A response to the attempted critique of the scientific phenomenological method", Journal of Phenomenological Psychology, Vol. 48, pp. 83144.

Giorgi, A. and Gallegos, N. (2005), "Living through some positive experiences of Psychotherapy”, Journal of Phenomenological Psychology, Vol. 36 No. 2, pp. 195-218.

Giorgi, A., Giorgi, B. and Morley, J. (2017), "The descriptive phenomenological psychological method", in: Willig, C. and Stainton Rogers, W. (Eds.), The SAGE Handbook of Qualitative Research in Psychology [online], SAGE, London, pp. 176-192. 
Giorgi, B. (2011), "A Phenomenological Analysis of the Experience of Pivotal Moments in Therapy as Defined by Clients", Journal of Phenomenological Psychology, Vol. 42, pp. 61106.

Gnoth, J. and Matteucci, X. (2014), "A phenomenological view of the behavioral tourism research literature", International Journal of Culture, Tourism and Hospitality Research, Vol. 8 No. 1, pp. 3-21.

Harper, W. (1981), “The Experience of Leisure”, Leisure Sciences: An Interdisciplinary Journal, Vol. 4 No. 2, pp. 113-126.

Holloway, I., Brown, L. and Shipway, R. (2010), "Meaning not measurement. Using ethnography to bring a deeper understanding to the participant experience of festivals and events", International Journal of Event and Festival Management, Vol. 1 No. 1, pp. 7485.

Husserl, E. (1965), Phenomenology and the Crisis of Philosophy, Translated from German by Quentin Lauer, (originally published in 1911), Harper \& Row, New York.

Husserl, E. (1982), Ideas Pertaining to a Pure Phenomenology and to a Phenomenological Philosophy, Book 1, General Introduction to a Pure Phenomenology, Translated from German by F. Kersten, (originally published in 1925), Kluwer Academic Publishers, Dordrecht.

Husserl, E., 1999. The crisis of European sciences and transcendental phenomenology. Translated from German by David Carr, (originally published in 1936), North Western University Press, Evanston, IL.

Husserl, E. (2001), The Shorter Logical Investigations. Translated from German by J.N. Findlay, (originally published in 1900/1913), Routledge, London.

Jackson, C., Morgan, M. and Hemmington, N. (2009), "Extraordinary Experiences in Tourism", International Journal of Tourism Research, Vol. 11 No. 2, pp. 107-109.

Langdridge, D. (2008), "Phenomenology and critical social psychology: directions and debates in theory and research", Social and Personality Psychology Compass, Vol. 2/3, pp. 1126-1142.

Matua, G.A. and Van der Wal, D.M. (2015), "Differentiating between descriptive and interpretive phenomenological research approaches”, Nurse Researcher, Vol. 22 No. 6, pp. 22-27.

Mayoh, J. and Onwuegbuzie, A.J. (2015), “Toward a Conceptualization of Mixed Methods Phenomenological Research", Journal of Mixed Methods Research, Vol. 9 No. 1, pp. 91107.

Paley, J. (1997), “Husserl, phenomenology and nursing”, Journal of Advanced Nursing, Vol. 26, pp. 187-193.

Paley, J. (2014), “Heidegger, lived experience and method”, Journal of Advanced Nursing, Vol. 70 No. 7, pp. 1520-1531.

Paley, J. (2017), Phenomenology as Qualitative Research, Routledge, Abingdon, Oxon.

Pernecky, T. (2016), Epistemology and methaphysics for qualitative research: constructing knowledge, Thousand Oaks, CA, SAGE Publications. 
Pernecky, T. and Jamal, T. (2010), “(Hermeneutic) Phenomenology in Tourism Studies”, Annals of Tourism Research, Vol. 37 No. 4, pp. 1055-1075.

Reiners, G.M. (2012), “Understanding the differences between Husserl's (Descriptive) and Heidegger's (Interpretive) Phenomenological Research", Journal of Nursing \& Care, Vol. 1 No. 5, pp. 1-3.

Rivera, M.A. and Pizam, A. (2013), "Advances in hospitality research: 'from Rodney Dangerfield to Aretha Franklin'", International Journal of Contemporary Hospitality Management, Vol. 27 No. 3, pp. 362-378.

Robinson, R.N.S., Solnet, D.J. and Breakey, N. (2014), “A phenomenological approach to hospitality management research: Chef's occupational commitment", International Journal of Hospitality Management, Vol. 43 No. 3, pp. 65-75.

Schutz, A. (1972), The Phenomenology of the Social World translated from German by George Walsh and Frederick Lehnert, (originally published 1932), Heinemann Educational Books, London.

Smith, J. (2016), Experiencing phenomenology: an introduction. Routledge, Abingdon, Oxon.

Smith, J.A. (2010), “Interpretative Phenomenological Analysis. A Reply to Amedeo Giorgi”, Existential Analysis, Vol. 21 No. 2, pp. 186-192.

Stebbins, R.A. (2018), "Leisure and the positive psychological states", The Journal of Positive Psychology, Vol. 13 No. 1, pp. 8-17.

Stierand, M.B. and Dörfler, V. (2012), "Reflecting on a phenomenological study of creativity and innovation in haute cuisine", International Journal of Contemporary Hospitality Management, Vol. 24 No. 6, pp. 946-957.

Thompson-Gee, J. (2017), “831,769 attend Summerfest 50”, available at: http://www.cbs58.com/news/831-769-attend-summerfest-50 (accessed 6 October 2017).

Todres, L. and Holloway, I. (2010), "Phenomenological Research", in Gerrish, K. and Lacey, A. (Eds), The research process in nursing, $6^{\text {th }}$ edition, Wiley-Blackwell, Oxford, pp. 177-187.

Todres, L. and Wheeler, S. (2001), “The complementarity of phenomenology, hermeneutics and existentialism as a philosophical perspective for nursing research", International Journal of Nursing Studies, Vol. 38 No. 1, pp. 1-8.

Tung, V.W.S. and Ritchie, J.R.B. (2011), "Exploring the essence of the memorable tourism experiences”, Annals of Tourism Research, Vol. 38 No. 4, pp. 1367-1386.

Van Manen, M. (1990), Researching lived experience: Human science for an action sensitive pedagogy, Althouse Press, London.

Vienna online (2017), "35. Wiener Donauinselfest goes from 22 to 24 June 2018”, 18 September, available at: http://www.vienna.at/35-wiener-donauinselfest-steigt-von22-bis-24-juni-2018/5463786 (accessed 5 October 2017).

Walls, A., Okumus, F., Wang, Y.C. and Kwun, D. (2011), "An epistemological view of consumer experiences”, International Journal of Hospitality Management, Vol. 30 No. 1, pp. 10-21. 
Zahavi, D. (2008), "Phenomenology", in Moran, D. (Ed.), Routledge Companion to Twentieth-Century Philosophy, Routledge, London, pp. 661-692.

Ziakas, V. and Boukas, N. (2013), "Extracting meanings of event tourist experiences: A phenomenological exploration of Limassol carnival”, Journal of Destination Marketing \& Management, Vol. 2, pp. 94-107. 


\begin{tabular}{|c|c|c|}
\hline Steps & Description & Commentary \\
\hline $\begin{array}{l}\text { 1. Concrete } \\
\text { descriptions }\end{array}$ & $\begin{array}{l}\text { This is the raw data of the } \\
\text { phenomenon, which is } \\
\text { given to the researcher, } \\
\text { usually through an } \\
\text { interview. }\end{array}$ & $\begin{array}{l}\text { - Phenomenological } \\
\text { interviews. } \\
\text { - } \text { Phenomenological } \\
\text { question } \\
\text { - } 3 \text { + Participants. }\end{array}$ \\
\hline $\begin{array}{l}\text { 2. Sense of the } \\
\text { whole }\end{array}$ & $\begin{array}{l}\text { Read for the whole, within } \\
\text { the attitude of } \\
\text { phenomenological } \\
\text { reduction, to get a holistic } \\
\text { understanding. }\end{array}$ & $\begin{array}{l}\text { - This influences all steps. } \\
\text { - Giorgi discusses the } \\
\text { singular. Applies to each } \\
\text { and then all transcripts. }\end{array}$ \\
\hline $\begin{array}{l}\text { 3. Meaning units } \\
\text { [Giorgi step 2] }\end{array}$ & $\begin{array}{l}\text { Every transition in meaning } \\
\text { from within the attitude } \\
\text { focused on the } \\
\text { phenomenon is marked. }\end{array}$ & $\begin{array}{l}\text { - Construction of parts } \\
\text { helps with the process of } \\
\text { analysis. } \\
\text { - These carry no theoretical } \\
\text { weighting. }\end{array}$ \\
\hline $\begin{array}{l}\text { 4. Transformations } \\
\text { [Giorgi step 3] }\end{array}$ & $\begin{array}{l}\text { Transforms the data, } \\
\text { through a method of free } \\
\text { imaginative variation, into } \\
\text { expressions that are more } \\
\text { relevant. }\end{array}$ & $\begin{array}{l}\text { - The 'heart of the method' } \\
\text { - Still essentially the words } \\
\text { of the participants. } \\
\text { - Goes through a number of } \\
\text { iterations. }\end{array}$ \\
\hline $\begin{array}{l}\text { 5. Constituents \& } \\
\text { Structure } \\
\text { [Giorgi step 4] }\end{array}$ & $\begin{array}{l}\text { The final expressions from } \\
\text { the transformations } \\
\text { undergo another stage of } \\
\text { free imaginative variation } \\
\text { to identify an essential } \\
\text { structure of the } \\
\text { phenomenon. }\end{array}$ & $\begin{array}{l}\text { This step is really two } \\
\text { integrated smaller steps to } \\
\text { identify: } \\
\text { - } 5 . \text { a constituents; } \\
\text { - } 5 . b \text { essential structure. } \\
\text { Eidetic intuitions beyond the } \\
\text { words. }\end{array}$ \\
\hline $\begin{array}{l}\text { 6. Communication } \\
\text { of the findings }\end{array}$ & $\begin{array}{l}\text { Clarification and discussion } \\
\text { of the data through the } \\
\text { identified constituents and } \\
\text { their interrelationships to } \\
\text { form the structure. }\end{array}$ & $\begin{array}{l}\text { Goes back to the } \\
\text { originating meaning units. } \\
\text { Interprets the } \\
\text { constituents through the } \\
\text { voices of the participants. }\end{array}$ \\
\hline $\begin{array}{l}\text { 7. Interpretation of } \\
\text { the structure } \\
\text { and constituent } \\
\text { parts } \\
\text { (new step) }\end{array}$ & $\begin{array}{l}\text { Discussion of the findings } \\
\text { with the extant relevant } \\
\text { literature. }\end{array}$ & $\begin{array}{l}\text { This resulted in discussion } \\
\text { sections that were a meta- } \\
\text { analysis of the } \\
\text { constituents. } \\
\text { - Widening the horizon of } \\
\text { the research into inter and } \\
\text { multi-disciplinary areas. }\end{array}$ \\
\hline
\end{tabular}

Table I. Descriptive phenomenology method steps

Sources: Giorgi (2008, 2009, 2012); Applebaum (2012); Broomé (2013). 
drinking culture with festivals, / um, but I'm, I got laughed at because I can't drink in the sun. Since I've got, I've got such a ginger complexion that it makes me really ill. So, I spent a lot of my time the Friday and Saturday in the shade, not drinking. / Um, but everyone had a few drinks and we got, one of the girls had a ukulele so we had a bit of a sing-song and, um, that was really nice, / and then headed down into the festival for the bands to begin. Um, I was quite surprised at, because the festival's quite big, um, or it's not, it's not as big as some of them, ah, it almost felt difficult to get to see some of the bands you wanted to. Because they have a Big Top tent area, um, but, like, I wanted to see The Vaccines playing there but you couldn't get near to it. So you were watching it on a screen outside and then, for me, live music isn't watching it on a screen. I want to see the band; you know, I want to see the musicians playing; um, I want to, ah, I want to watch it, but not through a screen. So, that annoyed me a little bit /

Figure 1. A sample of $\mathrm{P}_{2}$ transcript broken into three meaning units with a / 


\begin{tabular}{|c|c|c|c|}
\hline 1. Meaning units & 2. Third person & 3. Everyday language & ation \\
\hline $\begin{array}{l}\mathbf{P}_{2} \text { MU } \mathbf{1 1 0 .} \\
\text { um, but I'm, I got laughed } \\
\text { at because I can't drink in } \\
\text { the sun. Since I've got, } \\
\text { I've got such a ginger } \\
\text { complexion that it makes } \\
\text { me really ill. So, I spent a } \\
\text { lot of my time the Friday } \\
\text { and Saturday in the shade, } \\
\text { not drinking. }\end{array}$ & $\begin{array}{l}\mathrm{P}_{2} \text { was laughed at because } \\
\text { she was unable to drink in } \\
\text { the sunshine because of } \\
\text { her ginger complexion. } \\
\text { She spent a lot of the time } \\
\text { on the Friday and } \\
\text { Saturday in the shade and } \\
\text { not drinking. }\end{array}$ & $\begin{array}{l}\mathrm{P}_{2} \text { was the centre of fun } \\
\text { because, unlike others in } \\
\text { her party, she was unable } \\
\text { to enjoy drinking in the } \\
\text { sunshine a lot of the time } \\
\text { on the Friday and } \\
\text { Saturday. }\end{array}$ & $\begin{array}{l}\text { of the } \\
\text { he was } \\
\text { and lie }\end{array}$ \\
\hline $\begin{array}{l}\mathbf{P}_{2} \text { MU } 111 . \\
\text { Um, but everyone had a } \\
\text { few drinks and we got, } \\
\text { one of the girls had a } \\
\text { ukulele so we had a bit of } \\
\text { a sing-song and, um, that } \\
\text { was really nice, }\end{array}$ & $\begin{array}{l}\text { Everyone was able to } \\
\text { have a few drinks and a } \\
\text { sing-a-long because one of } \\
\text { the girls played the } \\
\text { ukulele. This put } \mathrm{P}_{2} \text { in a } \\
\text { better mood. }\end{array}$ & $\begin{array}{l}\mathrm{P}_{2} \text { was able to enjoy } \\
\text { herself because her } \\
\text { friends were able to drink } \\
\text { alcohol and they were all } \\
\text { able to sing along to } \\
\text { someone playing the } \\
\text { ukulele. }\end{array}$ & $\begin{array}{l}\mathrm{P}_{2} \text { and her friends got } \\
\text { ready for the festival by } \\
\text { drinking and lying in } \\
\text { the sun and singing } \\
\text { along to someone on } \\
\text { the ukulele. }\end{array}$ \\
\hline $\begin{array}{l}\text { P }_{2} \text { MU } 112 . \\
\text { and then headed down } \\
\text { into the festival for the } \\
\text { bands to begin. Um, I was } \\
\text { quite surprised at, } \\
\text { because the festival's } \\
\text { quite big, um, or it's not, } \\
\text { it's not as big as some of } \\
\text { them, ah, it almost felt } \\
\text { difficult to get to see some } \\
\text { of the bands you wanted } \\
\text { to. Because they have a } \\
\text { Big Top tent area, um, but, } \\
\text { like, I wanted to see The } \\
\text { Vaccines playing there but } \\
\text { you couldn't get near to it. } \\
\text { So you were watching it } \\
\text { on a screen outside and } \\
\text { then, for me, live music } \\
\text { isn't watching it on a } \\
\text { screen. I want to see the } \\
\text { band; you know, I want to } \\
\text { see the musicians playing; } \\
\text { um, I want to, ah, I want } \\
\text { to watch it, but not } \\
\text { through a screen. So, that } \\
\text { annoyed me a little bit. I } \\
\text { felt like they'd expanded } \\
\text { it in terms of having more } \\
\text { stages; they didn't think } \\
\text { about the viewing area for } \\
\text { those stages. I don't } \\
\text { know. }\end{array}$ & $\begin{array}{l}\mathrm{P}_{2} \text { and her friends then } \\
\text { headed down into the } \\
\text { festival for the bands to } \\
\text { begin. The scale of the } \\
\text { festival surprised her; } \\
\text { although she knew that it } \\
\text { was not as big as some. It } \\
\text { was the difficulty of being } \\
\text { able to see some of the } \\
\text { bands she wanted to } \\
\text { experience. For example, } \mathrm{P}_{2} \\
\text { wanted to see the Vaccines } \\
\text { but they were staged in the } \\
\text { Big Top tent and she was } \\
\text { unable to get near to it. She } \\
\text { had to watch them on a big } \\
\text { screen outside instead. This } \\
\text { annoyed } \mathrm{P}_{2} \text { because she } \\
\text { was at the festival to see the } \\
\text { band live and not on the big } \\
\text { screen. } \mathrm{P}_{2} \text { was interested in } \\
\text { each individual musician } \\
\text { and what they were doing } \\
\text { and was upset to have to } \\
\text { see them on a screen } \\
\text { because the festival was too } \\
\text { big for everyone to be able } \\
\text { to see who they wanted } \\
\text { close-up. }\end{array}$ & $\begin{array}{l}\mathrm{P}_{2} \text { was looking forward to } \\
\text { live music because she } \\
\text { could see the musicians } \\
\text { playing in the bands that } \\
\text { she liked. However she } \\
\text { found that the festival had } \\
\text { grown and bands like the } \\
\text { Vaccines were performing } \\
\text { in the Big Top that she } \\
\text { could not get into and had } \\
\text { to watch them on the big } \\
\text { screen. This meant that } \\
\text { she could not see the } \\
\text { musicians close-up and } \\
\text { live. P blamed the size of } \\
\text { the festival for this. }\end{array}$ & $\begin{array}{l}\text { ed that } \\
\text { see the } \\
\text { use she } \\
\text { the Big } \\
\text { were } \\
\text { watch } \\
\text { screen } \\
\text { I to be } \\
\text { Isicians } \\
\text { Iments. } \\
\text { hat } P_{2} \\
\text { led the } \\
\text { ival for }\end{array}$ \\
\hline
\end{tabular}

Table II. The transformation of the three meaning units from Figure 1 
Figure 2. The essential structure of the popular music festival experience 